\title{
„Potworna zdrada”. O źródłach kontrowersyjności adaptacji Doliny Issy
}

„Film Konwickiego z Doliny Issy mnie pasjonuje” - pisał do Czesława Miłosza Konstanty Jeleński 27 lutego 1981 r. w reakcji na informację od Miłosza, że powstał już scenariusz adaptacji. I dodawał o Tadeuszu Konwickim: „myślę, że potrafi on zrobić coś $\mathrm{b}\left[\right.$ ardzo] ciekawego" ${ }^{\text {. }}$. Wyczekiwany przez eseistę film powstał jeszcze w tym samym roku, reżyser ukończył go niedługo, jak się okazało, przed wprowadzeniem stanu wojennego.

Konwicki nie miał wpływu na dystrybucję (w tym wypadku: nie mógł wstrzymać dystrybucji), toteż film trafił na polskie ekrany w bez wątpienia bardzo niezręcznej dla twórcy Małej Apokalipsy sytuacji społecznej. Co gorsza, Dolina Issy była rozpowszechniana poza granicami kraju w ambasadach i ośrodkach kultury polskiej, reżyser mógł czuć się jak „łamistrajk” - tak gorzko podsumował swoją sytuację w wywiadzie rzece Pót wieku czyśćca $a^{2}$. Właśnie jednak dzięki „łamistrajkowemu” pokazowi miał szansę skonfrontować własne oczekiwania z powstałym utworem Jeleński. Podzielił się z Miłoszem swoimi wrażeniami w liście z 22 kwietnia 1983 r.:

Byłem wczoraj na pokazie Doliny Issy w Instytucie Polskim (gmach konsulatu) z Agnieszką Holland i jej 8-letnią córeczką. Gdybym był sam, wyszedłbym po pół godziny. Rzadko byłem równie wściekły na pokazie filmowym (w kinie): kicz, głupota, pretensjonalność potworna zdrada Twej książki! Jakiekolwiek uznanie moje czy sympatia dla Konwickiego skończyły się raz na zawsze. Zrobić coś

I C. Miłosz, K.A. Jeleński, Korespondencja, red. B. Toruńczyk, kwerenda, przepisanie listów z oryginałów H. Citko, skolacjonowanie listów, oprac. i przyp. R. Romaniuk, Warszawa 2011, s. 254.

${ }_{2}$ Zob. S. Bereś, Pótwieku czyśćca. Rozmowy z Tadeuszem Konwickim [1986], Kraków 2003, s. 159. 
podobnego z Dolina Issy może tylko człowiek nie tylko głupi, ale „zły” (w złym gatunku). Właściwie jeden Bergman mógł zrozumieć Twą książkę i coś z niej w filmie przekazać!3

Krótka epistolarna quasi-recenzja Jeleńskiego uderza w dwa aspekty filmu: w jego estetykę („kicz”, „pretensjonalność”) oraz w płaszczyznę intelektualną (Jeleński akcentuje jej brak: „głupota”, reżyser jako „człowiek [...] głupi” i nierozumiejący powieści). Do obu zaś kategorii - estetyki i kwestii intelektualnych - należy chyba określenie samego Tadeusza Konwickiego jako człowieka „w złym gatunku”. Wydaje się, że wyrażenie jest wzmocnieniem poprzedzającego je sformułowania („głupi”) i łączy się ze zdiagnozowaniem złego gustu. To samo dotyczy uznania filmu za „zdradę” powieści.

Warto jednak podjąć, wbrew Jeleńskiemu, te dwa ostatnie określenia i wykorzystać je przy rozpatrzeniu innej płaszczyzny filmu Dolina Issy. Wbrew Jeleńskiemu — ponieważ aby odkryć tę płaszczyznę, wypada mimo wszystko założyć istnienie pewnego ładunku refleksyjnego w tej adaptacji, czego Jeleński nie czyni bądź czynić nie chce. Jeśli przyjmiemy to założenie, wówczas mocne a nośne metaforycznie sformułowania: „zdrada” powieści oraz „człowiek [...] (w złym gatunku)”, zastosowane do rejestrów ideowych, okażą się doskonale oddawać istotę „konfliktu” artystycznego, jaki rozegrał się pomiędzy pierwowzorem a adaptacją, przede wszystkim zaś pomiędzy autorem pierwowzoru a autorem adaptacji. Bo jak najbardziej można by o Konwickim powiedzieć, że zdradził Miłosza w sensie ideowym, i jak najbardziej można by stwierdzić, że ideowo jest „w złym gatunku”, to znaczy w gatunku, jaki Miłosz (i Jeleński) uznają za zepsuty.

Tak się bowiem nieszczęśliwie - przynajmniej dla Miłosza (i Jeleńskiego jako odbiorcy) - zdarzyło, że rodzina poety noblisty poprosiła o dokonanie ekranizacji artystę o nie tylko diametralnie różnej w stosunku do Miłosza osobowości, ale i różnym zapatrywaniu na sztukę, na kwestie nie tylko estetyczne, ale i aksjologiczne. I zdarzyło się, że adaptator swoje zapatrywanie na sztukę odzwierciedlił w swej pracy. Konwicki utrzymywał i tuż po premierze, i w autokomentarzach po latach, że starał się być wierny Miłoszowi. Otóż nie był, przynajmniej na płaszczyźnie ideowej. $\mathrm{W}$ autokomentarzach tych zresztą $\mathrm{z}$ jednej strony podkreślał, że był niezwykle lojalny („Nie popełniłem w tym filmie najmniejszego nadużycia" ${ }^{4}$, podkreślał skrupulatność, $\mathrm{z}$ jaką oddawał na ekranie wybrane powieściowe wątki czy kom-

3 C. Miłosz, K.A. Jeleński, op.cit., s. 272.

4 S. Bereś, op.cit., s. 158. 
ponował dialogi, z drugiej jednak przyznawał: „poprawiłem mistrza! [śmieje się] Ja go «podpędziłem»!" ${ }^{5}$. Właśnie to żartobliwe stwierdzenie kryje w sobie istotę problemu, można je odnieść nie tylko do uatrakcyjnienia pierwowzoru nadaniem mu atmosfery nerwowości. Faktycznie bowiem głównie przez owo podpędzenie zakodowana jest w filmie manifestacja obcych Miłoszowi (i Jeleńskiemu) poglądów własnych Konwickiego. Miłosz pisał w Innym abecadle, że opowieść, „w której chodzi o konkretność, rzeczywistość postaci”, przeistoczyła się „w pasmo wspominków na granicy snu”, co przesądziło jednocześnie „o widmowości i rozchwianiu w akcji filmu" ${ }^{6}$. Elżbieta Kiślak komentuje zaś w artykule Prawda Konwickiego, prawda Miłosza: „U Miłosza dominuje dystans i ład, wyraźny kontur opisu, u Konwickiego namiętne emocje, poczucie nieprzejrzystości porządku świata, zacieranie granic" 7 .

Konwicki wyszedł z założenia, że jest to jego film, nie Miłosza (co nawet zastrzegł w samej konstrukcji filmu: ujawniając inscenizację wojennego rozstrzelania $-\mathrm{w}$ tym momencie pojawia się w kadrze jego odbicie). Takie właśnie miał zapatrywania na rolę adaptacji, zresztą zapatrywania nieprzypadkowo silnie akcentowane - jak przenikliwie zauważyła Kiślak - celowo w wypowiedziach stanowiących autokomentarz do Doliny Issy. Według Konwickiego adaptacja powinna przekazać myśl zawartą w oryginale, ale $\mathrm{z}$ autorską sygnaturą, $\mathrm{z}$ wypełnieniem nowo powstałego utworu także własnymi refleksjami. Ekranizacja to i obraz adaptatora, i świadectwo pewnej lektury tekstu, a więc swoistego dialogu dwóch artystów. Rzeczywiście Konwicki wykorzystał w filmie prawo do poruszania się po adaptowanym oryginale zgodnie ze wskazaniami własnej busoli.

„[...] adaptacja Doliny Issy zamiast uwydatnić wspólnotę rodowodu, litewskich doświadczeń, wyostrzyła różnice i ujawniła rozdźwięk między twórcami" - stwierdza Kiślak ${ }^{8}$, która w jednym $\mathrm{z}$ dwóch fundamentalnych dla badań nad filmem tekstów naukowych sonduje przyczyny tych różnic między Miłoszem a Konwickim, śledząc wypełnianie przez nich - w związku z filmem - „osobnych protokołów rozbieżności” 9 . Chciałbym dopisać tu swoistą glosę do pracy cytowanej badaczki.

5 Ibidem, s. 160 .

${ }^{6}$ C. Miłosz, Inne abecadto, Kraków 1998, s. 153.

7 E. Kiślak, Prawda Miłosza, prawda Konwickiego, „Litteraria Copernicana” 2008, nr 1: Konwicki, s. 145.

${ }^{8}$ Ibidem, s. 135.

9 Ibidem. Drugim najważniejszym artykułem jest praca T. Lubelskiego Krewniacy z Litwy. Narodziny adaptacji z ducha wspólnoty (, Kwartalnik Filmowy" 2007, nr 59). 


\section{Baltazar - Magdalena - Domcio}

„Rozebrałem Dolinę Issy na najdrobniejsze części, rozkręciłem do najmniejszych śrubek, obejrzałem sobie to wszystko i skręciłem całość na nowo, jakby w nowym kształcie oraz w innej funkcji" - pisze Konwicki o scenariuszu w swoim paradzienniku roku 1981 Wschody $i$ zachody księzyca ${ }^{\mathrm{IO}}$. Ma rację, nowy jest zarówno kształt całej konstrukcji, jak i jej funkcja.

Konwicki, tak jak podkreśla Kiślak, eksponuje w swojej adaptacji motyw poczucia winy, a widać to już choćby w skupieniu uwagi na postaci Baltazara ${ }^{\mathrm{II}}$. Motyw wyrzutów sumienia nie funkcjonuje jednak samoistnie, stanowi on jeden $\mathrm{z}$ aspektów szerszej kategorii, zresztą obecnej w filmie nie tylko przez wątek Baltazara. I w zasadzie należałoby chyba tę problematykę określić nieco ogólniej, jeśli chcielibyśmy objąć wszystkie motywy związane z każdym ważnym pod tym względem bohaterem; niektórzy przecież przekraczają normy i zakazy bez poczucia winy - jednak z całą świadomością występności, choć być może z wahaniem. Dlatego myślę, że Konwickiego jako autora tego filmu interesuje w ogóle problematyka grzechu, występku, zdrady, w tym także właśnie problematyka życia ze świadomością ciągłego sprzeniewierzania się jakimś wartościom, przekraczania norm moralnych i społecznych.

Baltazar faktycznie zostaje wysunięty na pierwszy plan. Widać to już w matrycy filmu: składa się ona z serii ujęć, zamykanych ujęciem zapalającej świecę kobiety - świeca rozjaśnia wówczas wijącego się w męczarniach jej męża. Gest mężczyzny zakrywającego dłońmi twarz jest pierwszym dramatycznym akcentem filmu i przykuwa uwagę odbiorcy, który domyśla się w tym ruchu zapowiedzi ważnego wątku. Sytuacja bohatera wyjaśniona zostanie zresztą już wkrótce, po pierwszym poetyckim intermedium (jak pamiętamy, Konwicki wplótł w film - czyniąc z niego tym samym swoisty esej filmowy - recytacje wierszy Miłosza, które skądinąd także stanowiły ognisko sporu ${ }^{12}$ ). Baltazar pojawi się po trzech krótkich scenach: po obrazie diabła Niemczyka w lesie, scence przędzenia w izbach dworu Surkontów (wątek Tomasza) i ukazaniu Magdaleny podającej pierogi księdzu Pe-

то T. Konwicki, Wschody i zachody księżyca [1982], Warszawa 2010, s. 87.

II Warto przypomnieć komentarz Konwickiego do uzyskanej w filmie atmosfery niepokoju: sugeruje ona, iż „każdego ścigają jakieś grzechy i duchy” (S. Bereś, op.cit., s. 158).

I2 Zob. E. Kiślak, op.cit., s. 142; por. interpretację funkcjonowania wierszy w adaptacji - T. Lubelski, op.cit., s. 161. Por. też C. Miłosz, Rozmowy polskie 1979-1998, Kraków 2006, s. 685-686 (wywiad S. Beresia). 
ikswie. Notabene to właśnie w rozmowie z owym Niemczykiem Baltazar opowie o swoich cierpieniach wewnętrznych, na co diabeł przypomni mu ich przyczyny - zabicie rosyjskiego sołdata w lesie (niebawem pokazane, i to w szerokiej, składającej się z dwóch części sekwencji).

W wymienionych wyżej scenkach sygnalizowany jest wszelako i inny wątek, który zdaje się zajmować jeśli mniej, to niewiele mniej ważne miejsce w filmie Konwickiego: wątek romansu Magdaleny z księdzem Peikswą. Obraz przechodzącej pomiędzy drzewami Magdaleny - już jako zjawy straszącej po okolicy z trzymanym za uzdę koniem - jest jednym z lejtmotywów filmu. Co jednak istotniejsze, ujęcia $\mathrm{z}$ tego wątku często sąsiadują w konstrukcji fabuły z ukazaniami Baltazara (raz zaś Baltazar z przerażeniem obserwuje Magdalenę ciągnącą za uzdę jego konia; dowodem, że to jego koń, jest odkryty później w stajni pot na sierści zwierzęcia). Jest to przyjęta w całym filmie koncepcja montażu i ma ona duże znaczenie dla wymowy adaptacji, buduje warstwę refleksyjną filmu: Konwicki wciąż zestawia ze sobą portrety postaci, nieustannie tasuje wątki, chętnie też przeplatając je sugestywnymi przerywnikami-wstawkami. Wydobywa w ten sposób pokrewieństwa problemowe zdarzeń, a także wspólne rysy bohaterów ${ }^{\mathrm{I} 3}$. Jeśli na przykład między wspomniane dwie części obrazu Baltazarowego morderstwa na sołdacie wkłada reżyser spotkanie Tomaszka i Onute nad jeziorami - to nie tylko po to, by na zasadzie kontrastu zderzyć ze sobą dwie tonacje i dać wytchnienie widzowi. Zostaje przecież wydobyta w takim kontekście pewna - oczywiście nie przymierzając do wagi morderstwa - grzeszność rozbierających się, zafascynowanych własną cielesnością dzieci. W każdym razie nie jest to przypadkiem, że wątek Magdaleny (i Peikswy) pojawia się w filmie w istotnym powiązaniu kompozycyjnym $\mathrm{z}$ wątkiem leśnika. Wybrzmiewa dzięki temu tragizm sytuacji kobiety, która targnęła się na swoje życie, i wybrzmiewają dzięki temu rozterki Peikswy. Warto zauważyć, że rozterki te były ukazane już w pierwszej, prezentującej postacie scenie: mężczyzna siedzi przy stole w ogromnym

${ }^{3}$ Jest to cecha charakterystyczna tych filmów Konwickiego, które można uznawać za eseistyczne, czyli Jak daleko stą, jak blisko, Dolina Issy, Lawa. Piszę o tym w pracach: Eseizacja prozy - eseizacja kina Tadeusza Konwickiego, w: Esej - sztuka - nauka, red. D. Lisak-Gębala, A. Małczyńska, Wrocław 2011; Lawa. Opowieść o „Dziadach” Adama Mickiewicza, Poznań 2008, zwłaszcza s. 49-55, 63-66; zob. także Konwicki ogladany, odczytywany, niedoczytany, „Studia Filmoznawcze” 2008, nr 29, s. 243. Por. autokomentarze dotyczące tej cechy twórczości: T. Konwicki, Pamflet na siebie [1995], Warszawa 2010, s. 84; idem, „Żagary”, w: Nowy Świat i okolice [1986], Warszawa 2010; idem, Pótwieku czyśćca, s. 158-159. 
napięciu, jakby walcząc ze sobą - co widz skądinąd początkowo niezupełnie rozumie, dopiero po chwili bowiem młody mężczyzna składa rękę i odsłania koloratkę, dając się rozpoznać jako ksiądz, i przytula się do kobiety.

Jest jednak i inna postać, która silnie koresponduje z wyżej wymienionymi. Znamienna jest 20. i 21. minuta filmu, krótka scenka procesji. Drugi raz na ekranie pojawia się w niej Peikswa: widzimy go, gdy niesie tabernakulum, a więc w sytuacji porażająco skontrastowanej z poprzednią, z jego zachowaniem na plebanii. Z tym kontrastem - zderzeniem wcześniejszej sytuacji intymnej, w której Peikswa okazywał się dźwigać ciężkie grzechy nieczystości i złamania ślubów celibatu, z sytuacją wynikającą z jego roli społecznej, dostępowania zaszczytu podnoszenia Ciała Bożego - połączony zostaje obraz Baltazara. Po cięciu montażowym ujęcia pochodu procesji Baltazar kieruje spojrzenie prosto $\mathrm{w}$ kamerę (widz rozumie, że kamera przybiera niejako punkt widzenia Ciała Bożego), po czym onieśmielony spuszcza wzrok, próbuje się przeżegnać i ostatecznie, nie dokończywszy gestu, nieomalże w popłochu ucieka. I w właśnie tym przejmującym momencie kamera skupia się na owej kolejnej, trzeciej, niezwykle ważnej postaci. Biegowi Baltazara przygląda się Domcio Malinowski: który też zaraz - zgodnie z kompozycyjnym rygorem filmu (koncentracji znaczących zdarzeń i spiętrzania emocji - wypluwa do chustki komunikant, który później będzie bezcześcić, testując gniew Boga.

Domcia, bohatera Miłoszowego, który rzeczywiście silnie intryguje adaptatora - bo i trudno, by nie fascynował Konwickiego taki eksperymentator - poznajemy już w scenie poprzedniej, miodobrania. To scena czystego piękna: płynnie poruszająca się kamera pokazuje chodzących wokół uli Tomasza i ciotkę Helenę, ubranych w białe kitle, w obłokach rozwiewanego przez nich wokół siwawego dymu do uspokajania pszczół. A wszystko przy dobiegających ze dworu dźwiękach pianina, bzyczeniu roju i odgłosie pobliskiej sygnaturki. I właśnie na rozlegający się nagle głos sygnaturki wcina się w kadr postać obserwatora sceny, Domcia. Wcina się on niepokojąco przez swój dystans, jego sylwetka zakłóca harmonię, wybija widza z rytmu sceny, w której jako odbiorca uczestniczy, sceny o niezwykle intensywnej poetyckości, otwierającej na metafizykę. Ten dysonans (przecięcie idylli podkreślane jest motywem ucieczki Tomaszka przed atakującymi go pszczołami), a w zasadzie zgrzyt - od razu buduje sugestię buntowniczej wobec sacrum postawy bohatera i w linii prostej zapowiada kulminacyjny punkt wątku Domcia, czyli przerażającą scenę, w której chłopak strzela do uwiązanego 
uprzednio psa. Scena strzelania rozpocznie się zresztą na podobnej zasadzie skontrastowania sielskiego początku z ciągiem dalszym: pies biegnie beztrosko przez łąkę i jest przyjaźnie przywoływany przez Domcia zagadującego do niego z uśmiechem.

Oczywiście taki bohater musi być świadkiem zakopywania trumny Magdaleny. Jest zresztą jednym z trzech mężczyzn zamykających wieko. $\mathrm{Z}$ przejęciem spogląda też na księdza Peikswę, który w tym momencie, nie doczekawszy zakopania samobójczyni, nagle odchodzi. Domcio jest wyraźnie zagubiony: mnie czapkę, przykłada ją dziecinnym gestem do piersi, obgryza paznokcie. Ostateczność, z jaką teraz obcuje, jest konsekwencją niebywałego obrazoburstwa, najśmielszego przekroczenia granicy, której okolice sam penetruje. Wypadek Magdaleny Domcio musi odbierać w kategoriach osobistych. Jej losem jest wstrząśnięty tym silniej, im bardziej fascynuje go postawa niezważania na religijne zakazy. Następna duża scena po tym fragmencie przedstawia właśnie obrażające Boga zabijanie psa.

\section{Wybory moralne}

Znamienny jest jednak i łańcuch wcześniejszych, następujących po zamknięciu wieka, ujęć. Spaja je motyw oglądania się za siebie postaci. Idący i przystający Peikswa - domyślamy się, że uciekający już z doliny - łączony jest w montażu ze stojącą, wyczekującą najpewniej kochanka Heleną. Nie przypadkiem z nią właśnie. Podobnie jak ksiądz, kobieta również zdradza przysięgę sakramentalną, przysięgę małżeńską. Wyakcentowana w ten sposób korespondencja dwóch wątków dopełniona zostanie zaś w finale trzecim elementem. Taki rodzaj zdrady okaże się bowiem pod koniec adaptacji ważnym aspektem konstrukcji postaci Babki Surkontowej - na łożu śmierci wyzna ona, choć w niedopowiedzeniu, że miała kiedyś pozamałżeński romans, którego owocem jest prawdopodobnie jej syn (mąż Heleny). Przypieczętowaniem problemowego zbliżenia wątków jest scena pośmiertnego tańca Magdaleny oraz Babki i ich rozmowy na wzgórzu.

Kategoria zdrady ma w filmie - jak zresztą i w książce - różne poziomy. $\mathrm{Z}$ wątkami zdrady erotycznej związany jest wątek zdrady swojej grupy społecznej. Tej dopuszcza się kochanek Heleny, Romuald, który zostawi uwiedzioną przez siebie kobietę, wiążąc się ze służącą, Barbarką, wbrew zakazowi przerażonej mezaliansem matki. Zważmy, że Romuald nie ma żadnych oporów, gdy podejmuje decyzje: romans z mężatką nie wzbudza w nim (skądinąd w Helenie chyba też) szczególnych refleksji 
natury etycznej ${ }^{14}$; co zaś do małżeństwa z Barbarką - pozostaje on niewzruszony na lamenty matki, czemu poświęcona zostaje duża scena $\mathrm{z}$ końca filmu.

Osobną płaszczyznę wypełnia problematyka innej zdrady - ideowej, związanej z koniecznością dokonania wyboru pomiędzy racjami równoważnymi a przeciwstawnymi. Te ostatnie - których istota leży de facto w poczuciu winy - są zresztą lejtmotywem twórczości Konwickiego. Określa go on jako motyw „trzech z wyrokiem”, symbolizujący kwestię „naporu historii na życie normalnego, szarego człowieka w tym kraju” ${ }^{\text {I5. }}$ Mówi o nim Konwicki w wywiadzie Pół wieku czyśćca:

Tu życie nie może toczyć się trybem zachodnioeuropejskim. Tam człowiek rodzi się, kończy szkołę, żeni się, rodzi dzieci, pracuje w banku, dorabia się, kupuje jacht, czyni dobro lub zło, a na koniec umiera. Tymczasem tutaj każdy musi nieustannie dokonywać wyborów moralnych, politycznych i światopoglądowych. A one nigdy nie są bezkarne! [...] Każdy z tych wyborów pociąga za sobą konsekwencje społeczne, moralne, a w najlepszym przypadku towarzyskie $^{\mathrm{I} 6}$.

A jest to, jak zresztą wzmiankuje w przywołanym wywiadzie i sam Konwicki, motyw silnie tętniący w jego twórczości $\mathrm{w}$ związku $\mathrm{z}$ momentem konwersji autora na komunizm na przełomie lat 40. i 50., czyli odwrócenia się od idei partyzantki antyradzieckiej z lat 1944-1945. To jeden z motywów newralgicznych, zwłaszcza w powieści Sennik wespótczesny, w której ten element właśnie tak bardzo podobał się Miłoszowi jako autorowi Historii literatury polskiej (o tym, co się w niej Miłoszowi nie podobało - niżej).

W filmie sygnalizowana jest ta problematyka w dwóch scenach: opowieści dziadka Tomasza o Hieronimie Surkoncie, słudze księcia Radziwiłła, oraz w późniejszej altankowej rozmowie Józefa Czarnego z Księdzem Monkiewiczem o wielkim księciu Witoldzie. Hieronim Surkont zdradził króla polskiego, przy-

${ }^{I} 4$ Pod tym względem to znowu typowy dla utworów Konwickiego bohater. Por. J. Walc, Tadeusza Konwickiego przedstawianie świata [1975], Warszawa 2010, s. 65: badacz podkreśla tu (akcentując różnice między prozą Konwickiego a literaturą romantyczną), że w dojrzałej twórczości Konwickiego „nigdy nie mamy do czynienia z sytuacją, w której bohaterowie mieliby jakiekolwiek obiekcje moralne wobec swojej miłości. W Senniku wspótczesnym Paweł uwodzi żonę Józefa Cara, swojego antagonisty, ale jak gdyby sam tego nie zauważa, nie czuje, iżby przekraczał jakieś normy moralne [...]".

${ }_{15}$ S. Bereś, op.cit., s. 205.

I6 Ibidem. 
stępując do sojuszu ze Szwedami, w przeciwnym jednak razie tłumaczy wnukowi dziadek - zdradziłby swego pana, księcia Janusza Radziwiłła. Przedłużeniem niejako tej rozmowy jest wypowiedź Józefa Czarnego - o bezradności Witolda, który nie mógł uratować Litwy, mając do wyboru albo stanąć ramię w ramię z Polakami przeciwko Krzyżakom, albo wystąpić przeciwko Koronie u boku Zakonu. Oba rozwiązania godziły w niezależność jego poddanych. W adaptacji motyw „naporu historii” przez rozległość czasową przykładów zyskuje więc wymiary w gruncie rzeczy ponadczasowe, dzięki czemu jeszcze silniej ilustruje nieustannie obecną u Konwickiego refleksję na temat społeczeństw tej części Europy.

\section{Spadanie}

Mimo że wszystkie wyżej wymienione motywy i postacie były obecne $\mathrm{w}$ powieści, to $\mathrm{w}$ filmie, przez ich intensyfikację, przez takie wyakcentowania ich elementów i zatopienie w rozedrganej, wybitnie niemiłoszowej konstrukcji, zostają - by sięgnąć po określenie, którym posłużył się Tadeusz Lubelski - zawłaszczone przez świat wyobraźni Konwickiego ${ }^{\mathrm{I7}}$. Reżyser rozsiewa przy tym dyskretnie w tkance filmu słowa utwierdzające status $q u o$. W scenie polowania Romuald wypowiada na przykład znamiennie przekształcone przez adaptatora polecenie - by jeden z myśliwych, Wiktor, szedł czatować „na Powstańczą Łąkę”. Nie, jak u Miłosza, „na Czerwoną Łąkę" ${ }^{\text {I8 }}$ I jest to, rzecz jasna, Powstańcza Łąka z książek i świata Wileńszczyzny Konwickiego. Jeśli zaś Barbarka mówi do Romualda o lubczyku na rojstach wypowiada tytułowe dla debiutanckiej powieści Konwickiego słowo bynajmniej nie jako wzięte $\mathrm{z}$ dialogu przejętego z Miłosza (pada ono w książce w sumie trzykrotnie, ale w innych kontek$\left.\operatorname{stach}^{\mathrm{I} 9}\right)$, tylko właśnie czyniąc $\mathrm{z}$ niego sygnaturę autorską Konwickiego.

O ile jednak te elementy można by ostatecznie odczytywać przez ich wileńską proweniencję, czyli jako znaki bliskości obu twórców, co według Konwickiego predestynowało go przecież do adaptowania Doliny Issy (kategorię „krewniaków z Litwy” opisuje w swoim tekście Lubelski) - o tyle istnieją elementy filmu już ewidentnie, wyłącznie „konwickie”, jego własne. Jest ich bardzo niewiele, niemniej są. Otóż Konwicki dopisuje do fabu-

\footnotetext{
${ }^{17}$ T. Lubelski, Siedem powodów niezbędności, „Kino” 2001, nr 6, s. 10-11.

I8 Por. C. Miłosz, Dolina Issy [1955], Kraków 1999, s. 126.

I9 Por. ibidem, s. 210, 244, 271.
} 
ły powieściowej nowe elementy akcji. Poza wspomnianą wyżej jawnie reżyserowaną sceną wojenną, która poprzedza recytację wiersza Obłoki w wykonaniu Józefa Duriasza, mamy też scenkę współczesną poprzedzającą recytację Stońca przez Jerzego Kamasa, w której grana przez aktora postać budzi się w amerykańskim mieszkaniu na mirażowy odgłos czyjegoś dobijania się do drzwi. Co podkreśla w ten sposób Konwicki? Oczywiście trwałość i niezbywalność tego doświadczenia, które wydobędzie $\mathrm{z}$ tkanki powieści w motywach wyborów władców historycznych. Mężczyźni dobijający się w majaku postaci Kamasa do drzwi to przecież nowi „trzej z wyrokiem” Konwickiego. Taki akcent $\mathrm{w}$ fabule znowu zresztą sprzeczny jest $\mathrm{z}$ koncepcją Miłosza, jak zaznacza Kiślak:

Powieść miała stanowić odtrutkę na fatalizm dziejów, tymczasem $\mathrm{w}$ filmie ucieczka przed traumatycznym doświadczeniem historii jest niemożliwa nawet za oceanem. Konwicki naznaczył obraz własną obsesją - nie ma w jego adaptacji żadnego katartycznego wyzwolenia, powraca nieuleczalna trauma, ujawniająca bezbronność całej jego generacji wobec ciśnienia historycznych wydarzeń, i niepokojące poczucie ciągłego zagrożenia $[\ldots]^{20}$.

Motyw ten, jak cała oniryczna konstrukcja filmu, są jednak pochodną nie tylko lęków, ale i poglądów Konwickiego na świat, wyrażających się właśnie w jego twórczości prozatorskiej i filmowej, już w samym sposobie kreowania świata przedstawionego, w narracji, czy też ściślej: w destrukcji narracji, jak określa to Jan Walc, oznaczającej - by zacytować bodaj najsłynniejszą formułę z przywołanej pracy badacza - „pisarską

${ }^{2 \circ}$ E. Kiślak, op.cit., s. 143. W dość podobnych kategoriach ujął ślad doświadczenia swojej generacji w tym filmie sam Konwicki (dystansując się przy tym - nie wiem, czy w tym wypadku sprawiedliwe - od powieści Dolina Issy), uczynił to zresztą w wywiadzie, którego udzielił tuż przed pracą nad filmem. Kiedy rozmówczyni Konwickiego, Janina Szymańska, mówi, że okrucieństwo, które pojawia się w książce Miłosza, to „okrucieństwo wyobraźni”, Konwicki zaś w adaptacji urealnia je („U ciebie przechodzi w okrucieństwo życia”), reżyser odpowiada: „Książka Miłosza jest czymś w rodzaju Pana Tadeusza - utworem napisanym w pewnej tradycji literackiej, konwencji i symbolice. A refleksy manichejskie zbliżają pana Czesława do pana Jarosława [Iwaszkiewicza]. Nie mówię tego, żeby przyczepiać się do utworu laureata Nobla, ale jego książka podległa stylizacji. Ja jestem cały stworzony przez epokę pieców wojny i prawdziwe okrucieństwa, a nie literackie, zmusiły mnie, żeby patrzeć bardziej realistycznie na naszą egzystencję. Jesteśmy z innej generacji i może z innych warstw kulturowych. On trochę arystokrata, a ja plebej. Stąd też poza tym, że się lubimy, nie ma komunikacji między nami” (J. Szymańska, Jestem po prostu pierwszym widzem, „Ekran” 1981, nr 47). 
deklarację niekompetencji w zakresie przedstawiania świata" ${ }^{21}$. Konwicki w swojej popaździernikowej twórczości poszukuje języka i tylko próbuje uchwycić obrazy świata, nie będąc pewnym efektów. Języka tego poszukuje w subiektywizmie, tak bardzo obcym Miłoszowi.

Świat Konwickiego to świat zagubionego człowieka, niewidzącego aksjomatów. Najgłębsze fundamenty konstrukcji fil$\mathrm{mu}$ - konstrukcji odrzucanej przez Miłosza - leżą właśnie w takiej postawie: postawie odrzucanej przez Miłosza. Tak a nie inaczej komponując film, Konwicki sprzeniewierzył się Miłoszowemu widzeniu świata. Z powieści Miłosza - który podnosi w swojej twórczości obiektywizm, sprawdzalność, policzalność, namacalność świata jako wartość, nieodzowną do poruszania się w świecie - Konwicki nakręcił film manifestacyjnie nihilistyczny. Nihilistyczny w znaczeniu, jakie nadaje terminowi Michał Januszkiewicz w odniesieniu do twórczości Tadeusza Różewicza ${ }^{22}$. Konwicki tak jak Różewicz poszukuje bowiem owych niewidzianych aksjomatów, podważa zastałe tropy, sprawdzając je, bo dotkliwie odczuwa brak trwałego oparcia we współczesnym świecie. Przywołanie przeze mnie w tym kontekście sporu Różewicza jest zresztą celowe. Wszak to między innymi do twórczości tego poety porównał Sennik wspótczesny Miłosz, dystansując się w prywatnej korespondencji od zawartej w powieści takiej wizji świata:

[...] jak Przybyszewskiemu brakowało złożoności intelektualnej i miękkości dotyku, tak oni w czerń absolutną (bo Boga nie ma). Są w tej książce rzeczy potężne i przerażające (sceny z partyzantki antysowieckiej na Wileńszczyźnie - rzędy sań obwożące w noc grudniową zamrożone trupy akowców dla postrachu ludności - dzieło NKWD), ale utopione to w znęcaniu się nad życiem w ogóle, czyli w taniochach. Vide Różewicz, vide Kazio Brandys ${ }^{23}$.

By rozważyć tak zdeprecjonowany punkt widzenia samego Konwickiego (i Różewicza, prawdopodobnie także Brandysa, wspomnianego tu przez Miłosza) na kwestię rozpoznawania świata i aksjomatów, dobrze jest przywołać kontekst nieco późniejszych od Sennika... utworów Konwickiego, tych z przełomu lat 60. i 70., i wywołanych przez nie dyskusji recenzyjnych. Kilka lat po tym bowiem, jak niektórzy wpływowi krytycy kra-

${ }^{2 I}$ J. Walc, op.cit., s. 17.

${ }_{22}$ M. Januszkiewicz, Różewicz - nibilista, „Teksty Drugie” 2007, nr 3, s. $42-57$.

23 A. Wat, Korespondencja, cz. 2, oprac. A. Kowalczykowa, Warszawa 2005, s. 292. 
jowi odrzucili Wniebowstapienie i Nic albo nic... - podważając zasadność mrocznego, depresyjnego, „desperującego” przesłania tych powieści ${ }^{24}$, jeszcze silniej zaznaczającego się wszakże niż w Senniku... - Konwicki uznał za konieczne sformułowanie w Kalendarzu i klepsydrze autokomentarza dotyczącego jego „rozpaczy”. Metaforycznego co prawda, ale zupełnie jasnego. Podkreślił, że wynika on ze ściśle pokoleniowego doświadczenia: $\mathrm{z}$ tragicznie zawiedzionych nadziei.

Ja stoję tu [...] - wyznawał ironicznie Konwicki - jak wcześnie spróchniały dębczak, i nie oddaję brzmieniem swego biednego wnętrza głosu tych zefirków, wichrów i huraganów, co mną targają. Ja słucham swego własnego buczenia, w którym gadają umęczone, czyśćcowe duchy ludzi, co kiedyś chcieli tę ziemię przeistoczyć w ziemię obiecaną dla wszystkich nieszczęśliwych, zniewolonych i tyranizowanych całego świata ${ }^{25}$.

Takie buczenie, w którym słychać gorzkie rozczarowanie światem wzniesionym po wojnie, na gruzach starego, rozczarowanie także fiaskiem własnych prób uczestniczenia w budowie tego nowego świata, zakodowane jest między innymi w wizji wszechobecnej agonii we Wniebowstapieniu ${ }^{26}$ oraz w wielokrotnie omawianej w badaniach konstrukcji Nic albo nic... Pierwszy wątek drugiego $\mathrm{z}$ tych utworów zamyka modlitwa nad ciałem zastrzelonego Niemca - „Niech mój świat będzie czysty. Niech mój świat będzie sensowny jak kłos dojrzałego zboża. Niech mój świat będzie po raz pierwszy piękny" ${ }^{27}$ - a kolejne wątki świadczą dobitnie, że wyrażone w tym monologu bohatera pragnienie

${ }^{24}$ Najdobitniej podważał je, jak wiadomo, Julian Przyboś w recenzji z Wniebowestapienia (1967) - Koszmary nocy („Życie Warszawy” 1967, nr 306) - oraz w polemicznym wobec głosu Henryka Berezy (Zstapienie na ziemię, „Twórczość” 1968, nr 3-4, s. 110-113) tekście Desperacjonizm, czyli kult rozpaczy („Miesięcznik Literacki” 1968, nr 9). Jako jeden z czołowych piewców „desperacjonizmu" - i adresat krytyki - wskazywany jest przez Przybosia oczywiście i Różewicz. Nie jest moją intencją porównywanie lektury Przybosia z odbiorem Miłosza; Przyboś pojawia się tu z tego powodu, że zawdzięczamy mu ważki - sformułowany kilka lat przed nakręceniem Doliny Issy - autokomentarz Konwickiego. Szerzej na temat ostrych komentarzy (także np. W. Kubackiego, J. Preger, recenzujących Nic albo nic...) i reakcji Konwickiego piszę $\mathrm{w}$ poświęconym Kalendarzowi i klepsydrze fragmencie rozdziale IV monografii tej twórczości (książka w przygotowaniu do druku).

25 T. Konwicki, Kalendarzi i klepsydra [1976], Warszawa 2010, s. 203.

${ }^{6}$ Piszę o tym w artykule Noc dożynek. Problematyka śmierci we „Wniebowstapieniu”, „Litteraria Copernicana” 2008, nr 1: Konwicki, s. 103-131.

${ }_{27}$ T. Konwicki, Nic albo nic. Kronika wypadków mitosnych, Warszawa 2010, s. 80 . 
bynajmniej się nie ziściło. Adaptacja Doliny Issy stanowi kontynuację między innymi tych dzieł, stanowi element przynależny do większej całości, czyli rozbudowywanego przez Konwickiego z utworu na utwór artystycznego obrazu świata jako padołu niespełnień, zawodów, niepokoju i poczucia winy. Obrazu, który skądinąd Konwicki dopełniał także cytatami z Różewicza, jak zdarzyło się w o dwa lata wcześniejszym od Wniebowstapienia filmie Salto (recytacja fragmentów Spadania w centralnym momencie fabuły) i w popaździernikowym Ostatnim dniu lata (w słowach z prologu rozpoznajemy przecież zwrotkę Głosów). Adaptacji Doliny Issy dokonał członek generacji, której duchowa kondycja przez Różewicza określona została metaforą „przetrąconego grzbietu" ${ }^{28}$.

Symboliczne dla sporu Miłosza i Konwickiego jest zderzenie w tej adaptacji ukrytego wzoru powieściowego - Pana Tadeusza - z ukrytym wzorcem adaptacji - Dziadami. Konwicki zrobił ten film, jak podkreślał w autokomentarzu, jako Dziady $y^{29}$, stosując zresztą - dopowiedzmy - kontynuację formuły użytej dziesięć lat wcześniej w filmie Jak daleko stad, jak blisko i zapowiadając o siedem lat późniejszą filmową Lawę.

Do wymienionych wyżej punktów „konwickich” w filmie należy dodać w tym miejscu jeszcze jeden ważny element. We wspomnianej scenie, w której Domcio, prowokując Boga, zabija psa, bohater wypowiada prosto do kamery słowa:

Jeżeli człowiek jest dla psa tym, czym Bóg dla człowieka, to kiedy pies ugryzie człowieka, ten łapie za kij, a Bóg ugryziony przez człowieka też wpadnie w gniew i ukarze. Cała rzecz to wynaleźć coś tak obrażającego Boga, żeby musiał użyć swoich piorunów. Jeżeli wtedy

${ }_{28}$ W wierszu z tomu szara strefa (Wrocław 2003) - wierszu co prawda niemającym tytułu ani dedykacji, ale którego adresatem lirycznym jest bez wątpienia Konwicki (zob. motto z Zórz wieczornych) - pisze Różewicz: „[...] najlepiej byłoby zwariować/ masz rację Tadziu/ ale nasze pokolenie nie wariuje/ do końca/ ma oczy otwarte// nam nie trzeba zawiązywać oczu/ nam niepotrzebne są raje/ różnych wiar sekt religii// z przetrąconym grzbietem/ czołgamy się dalej” (s. 27).

${ }_{29}$ T. Konwicki, Pół wieku czyśćca, s. 156. Formuła miałaby polegać na tym, że „wszystko dzieje się pomiędzy wieczorem a świtem. W tym czasie trzy razy pieje kur. [...] Postacie w tym obrzędzie od czasu do czasu wychodzą na plan pierwszy w «cywilu», dają komentarz i powracają do umownej, obrzędowej akcji, która jest jednonocną psychodramą niczym nocne Polaków rozmowy” (ibidem). 
nic się nie stanie , dowód zostanie przeprowadzony, że o Niego dbać nie warto $^{3 \circ}$.

Słowa są wzięte z powieści, choć w samym pierwowzorze nie padają w dialogu, tylko w narracji kreślącej logikę czynów eksperymentatora. Możemy się domyślić, że gdyby to mówił Domcio, nie można by słowa „Niego” zapisać wielką literą. Narrator powieści zapisuje je tak, ponieważ dla niego Bóg istnieje. Jak oddaje to w tkance filmu Konwicki? Dzieje się w scenie coś, czego nie ma w fabule Miłosza: słychać grzmot. I jest to grzmot z jednej strony jak najbardziej wierny samej powieści (jakkolwiek w samej powieści niepojawiający się), z drugiej jednak mimo wszystko ryzykowny. Z jednej strony jest miłoszowski, ale z drugiej jest to sygnatura Konwickiego, przedkładającego ponad Pana Tadeusza poema drezdeńskie.

Sygnatura z perspektywy lat wydaje się o tyle wyrazistsza, że odsyła widza w przyszłość, do adaptacji Dziadów - jest to przecież grzmot właśnie tego pioruna, który zabija Doktora w scenie Balu u Senatora, pioruna stanowiącego też punkt kulminacyjny (klimaks) fabuły Lawy. Tym samym Konwicki okazuje się i lojalny wobec Miłosza, i zdradzający go. Tak dzieje się w całej adaptacji. Jej losy same w sobie mogą stanowić kolejną ilustrację problematyki nurtującej Konwickiego i stanowiącej, o czym była mowa, jeden z najważniejszych lejtmotywów samego filmu: zdrady mimowolnej, nieuchronnej.

\section{PRZEMYSŁAW KANIECKI}

\section{"Monstrous Betrayal": On the Sources of the Controversy around the Film Adaptation of Dolina Issy [The Issa Valey]}

The author attempts to identify the origins of the famous argument between Miłosz and Konwicki about the film adaptation of Dolina Issy. Konwicki created a film which, although it is an adaptation of the novel, clearly belongs to his own creative output, focused on axiological uncertainty after The Second World War. Konwicki's work is a record of a quest for enduring points of reference, a quest conducted with realisation that such points cannot be found by a person who feels lost in the modern world. Such a world-view was not acceptable for Miłosz, and it is difficult to expect that the poet would accept an adaptation of his novel created from such a point of view. 
Keywords: Tadeusz Konwicki, Czesław Miłosz, Tadeusz Różewicz, film adaptation, nihilism, guilt, Vilna.

Przemysław Kaniecki - doktor, zatrudniony w Instytucie Badań Interdyscyplinarnych „Artes Liberales“ UW, współpracownik Muzeum Historii Żydów Polskich. Zainteresowania badawcze: polska kultura po roku 1945 (proza, kino), zwłaszcza twórczość Tadeusza Konwickiego. Autor m.in. książkowego opracowania Lawy (2008), opublikował też wywiad rzekę z pisarzem - Wpośpiechu (2011). Z prac redakcyjnych: poświęcony twórczości Konwickiego numer pisma „Litteraria Copernicana” (numer inauguracyjny: nr 1/2008, oprac. z J. Speiną) i tom Wiatr i pyt - wybór jego mniejszych form prozatorskich (oprac z T. Lubelskim, 2008). Z prac edytorskich: seria „Książek wybranych” Tadeusza Konwickiego (2010).

e-mail:p.kaniecki@gmail.com 